\title{
A Comparative Study Between Two Different Doses of Dexmedetomidine Combined with Ropivacaine in Ultrasound Guided Supraclavicular Brachial Plexus Block
}

\author{
Jeevan Singh, ${ }^{1}$ Samir Shakya, ${ }^{1}$ Anuranjan Ghimire, ${ }^{1}$ Sanjay Saha, ${ }^{1}$ Parikshit Bikram Singh ${ }^{1}$ \\ ${ }^{1}$ Kathmandu University School of Medical Science, Dhulikhel, Kavre.
}

\begin{abstract}
Background: Though, various studies have been conducted to show the efficacy of dexmedetomidine as an adjuvant to brachial plexus block, there is no clear consensus for its optimal dose. We compared 2 different doses of dexmedetomidine $(1 \mathrm{mcg} / \mathrm{kg} \mathrm{Vs} 2 \mathrm{mcg} / \mathrm{kg})$ with ropivaciane in USG guided brachial plexus block for the quality of anesthesia and analgesia. Materials and Methods: Fifty patients (18-50years, 50-60kgs), ASA PS I and II undergoing surgery of upper limb were enrolled in this prospective, double blind, randomized control trial. Group Rd received $19 \mathrm{ml}$ of $0.5 \%$ Ropivaciane with $1 \mathrm{mcg} / \mathrm{kg}$ of dexmedetomidine (total $20 \mathrm{ml}$ ), and Group RD received $19 \mathrm{ml}$ of $0.5 \%$ Ropivacaine with $2 \mathrm{mcg} / \mathrm{kg}$ of dexmedetomidine (total $20 \mathrm{ml}$ ). Onset and duration of sensory and motor block, duration of analgesia, sedation score, hemodyanamic changes were compared. We also monitored for various un towards effects. Results: The onset time of sensory and motor block $(9.36 \pm 1.114$ mins and $14.40 \pm 1.528 \mathrm{mins}$ in group $\mathrm{Rd}$ vs $8.32 \pm 0.945 \mathrm{mins}$ and $12.40 \pm 1.21 \mathrm{mins}$ in group RD) were not significantly different between two groups ( $\mathrm{p}$-value $>0.05$ ). The duration of sensory and motor block (596.20 \pm 76.859 mins and 541.20 \pm 81.564 mins in group Rd vs $730.80 \pm$ 65.187 mins and 659.80 \pm 93.607 mins in group RD) were not significantly longer in group RD than group $\mathrm{Rd}$ ( $\mathrm{p}$-value $>0.05)$. The duration of analgesia $(626.00 \pm 70.475 \mathrm{mins}$ in group $\mathrm{Rd}$ vs $754.00 \pm 60.139$ mins in group RD) were not significantly longer in group RD than group Rd (pvalue $>0.05$ ). Hemodynamic parameters were also comparable between two groups ( $p$-value $>0.05$ ) but 3 patients in RD group $(2 \mathrm{mcg} / \mathrm{kg})$ developed bradycardia and required treatment with atropine whereas in Rd group $(1 \mathrm{mcg} / \mathrm{kg})$ none developed bradycardia. Conclusions: There is no significant difference in the onset and duration of block between the two groups. However, higher dose of dexmedetomidine is associated bradycardia. Hence, in comparision with $2 \mathrm{mcg} / \mathrm{kg}, 1 \mathrm{mcg} / \mathrm{kg}$ of dexmedetomidine is better adjuvant to $0.5 \%$ ropivaciane in terms of safety and effectiveness.
\end{abstract}

Keywords: dexmedetomidine; ropivacaine; supraclavicular brachial plexus block.

\section{INTRODUCTION}

Supraclavicular brachial plexus blocks in orthopedic surgical procedures of upper limb provides fast, complete and dense analgesia with the advantage of good post-operative analgesia and improved patient comfort, ${ }^{1}$ but the effect tends to wear off rapidly due to high vascularity of the site. ${ }^{2}$ Various analgesic adjuvant to brachial plexus block are used to reduce the onset time, prolong the analgesic and motor blockade effect without the disadvantages of systemic side effects and reduce total dose of local anesthetic requiered. ${ }^{3-6}$ Alpha-2 adrenergic receptor agonists (clonidine and dexmedetomidine), due to its excellent sedative, analgesic, antihypertensive, anesthetic sparing and hemodynamic stabilizing properties, have also been used efficaciously and safely as an adjuvant to local anesthetic agents in regional nerve blocks. ${ }^{7,8}$ Dexmedetomidine in the dose ranges of $0.5-2 \mathrm{mcg} /$

Correspondence: Dr. Jeevan Singh, Department of Anaesthesia, Kathmandu University School of Medical Science, Dhulikhel, Kavre, Nepal. Email: jeevanji675@gmail.com. Phone: +977-9851029933. DOI: dx.doi.org/10.3126/jcmsn.v\%vi\%i.20908. Article received: 2018-08-29. Article accepted: 2018-09-20. 
$\mathrm{kg}$ has been used as adjuvant to regional nerve block in various studies with various degree of side effect. ${ }^{9}$ A dose of $150 \mathrm{mcg}$ of dexmedetomidine has been associated with minimal side effects, ${ }^{10}$ but other studies have shown that dexmedetomidine even at $30 \mathrm{mcg}$ can cause significant compromise, ${ }^{11}$ which challenges its use in peripheral nerve blocks in day care surgeries. Besides, there is no study suggestive of any appropriate dose of dexmedetomidine as an adjuvant in supraclavicular brachial plexus block.

Although, there are several studies showing the efficacy of dexmedetomidine as an adjuvant, there is no clear consensus regarding an ideal dose to be used. We are trying to determine an optimum dose of dexmedetomidine which provides maximum improvement in block characteristics with minimum untowards effects. So, this study is performed with primary aim of assessing the duration of analgesia of two different doses of dexmedetomidine, $1 \mathrm{mcg} / \mathrm{kg}$ and $2 \mathrm{mcg} / \mathrm{kg}$ added to $0.5 \%$ ropivacaine (plain), in patients posted for upper limb surgeries.

\section{MATERIALS AND METHODS}

Fifty patients of ASA I and II, aged (18-60) years, weighed (50-60) kilograms undergoing upper limb surgeries under supraclavicular brachial plexus block were studied according to double blind protocol approved by our institutional research committee. Patients with known sensitivity to local anesthesia or dexmedetomidine, second and third degree heart block, renal and hepatic insufficiency, uncontrolled diabetes mellitus and hypertension, on adrenergic agonist or antagonist therapy, pregnant and lactating women, alcohol and drug abuse; psychiatric disorders, neuromuscular disorder, coagulopathy, patient refusal, subsequent pneumothorax, patchy or inadequate anesthesia requiring conversion to general anesthesia or when additional opioid or sedation required were excluded from participation in this study.

Group assignment were enclosed in a sealed envelope to ensure concealment of allocation sequence. The sealed envelope was open by an anesthesiologist not involved in the study who then prepare the drug solution according to randomization. The anesthesiologist performing the block and observing the patient were blinded to treatment groups. Data collection was done by anesthesiologist who will be unaware of the group allocation. Patients were randomly assigned to one of the two groups. The $10 \mathrm{~cm}$ visual analogue scale (VAS) (0-no pain and 10-worst pain) was explained during pre-operative visit. All patients received tablet lorazepam $2 \mathrm{mg}$ orally on the night before surgery.A non-invasive monitor with blood pressure, oxygen saturation ( $\mathrm{SpO} 2)$, electrocardiogram (ECG) wasattached, and their baseline values were recorded. Intravenous(IV) assess was established using $20 \mathrm{G}$ cannula and IVfluid(Ringer's lactate) was started at $100 \mathrm{ml} / \mathrm{hr}$. Under all aseptic condition, supraclavicular brachial plexus block was performed with the help of ultrasonography (USG).

Patients in group $\mathrm{Rd}$ received $19 \mathrm{ml}$ of $0.5 \%$ ropivacaine plus $1 \mathrm{mcg} / \mathrm{kg}$ of dexmedetomidine diluted in $1 \mathrm{ml}$ of normal saline (total $20 \mathrm{ml}$ ). Patients in group RD received $19 \mathrm{ml}$ of $0.5 \%$ ropivacaine plus $2 \mathrm{mcg} / \mathrm{kg}$ of dexmedetomidine.

Sensory and motor blockades were assessed for every 2 mins after completion of injection till 30 mins and then every hourly after the end of surgery till the first 12 hours, thereafter 2 hourly until the effect of block. For sensory loss assessment, we used pinprick test with a 3-point scale $^{11}$ : 0 - no block, 1 - analgesia [loss of sensation to pinprick] and $2-$ loss of touch in the distribution of median, ulnar and radial nerve. Motor blockade was assessed by modified Bromage scale for upper extremities using 3-point scale $^{12}: 0$ - complete movement of finger and wrist, 1 - ability to move the fingers only, 2 inability to move fingers.

Onset of sensory blockade was defined as the interval between the end of injection and sensory block evidence by loss of sensation to pinprick or by score of 1 . Onset of motor blockade was defined as the interval between the end of injection and complete paralysis of wrist or score of 1. Duration of analgesia was taken as time interval between the onset of sensory block and the first dose of rescue analgesia given to the patient. A complete block was defined as block with grade 2 score. Patients with score of 0,1 was consider having incomplete block and was exclude from the study.

Post-operative pain assessment was done using VAS for every 2 hours till the block last. Post operative heart rate(HR), systolic(SBP), diastolic (DBP) and mean blood pressure(MBP) and $\mathrm{SpO} 2$ were recorded for every 5 mins for 30 mins, every 15 mins till $2 \mathrm{hrs}$, every $30 \mathrm{mins}$ till 6hours, every 2 hourly till the effect of block. Rescue analgesia was provided with inj. diclofenac sodium $75 \mathrm{mg}$ intramuscularly when $\mathrm{VAS} \geq 3 \mathrm{~cm}$. The number of 
diclofenac injections given to each patient during first 24 hours of postoperative period was recorded. The incidence of side effects (bradycardia, hypotension and sedation) were recorded. Sedation was assessed using 4 point sedation $\operatorname{score}^{8}(0-$ awake, 1- drowsy, 2- sleeping but arousable on verbal command, 3 - sleeping and arousable only on tactile stimulation). Bradycardia was defined as decrease in HR by $20 \%$ from baseline value or an absolute HR $<50$ beats per minute; which was managed by $0.6 \mathrm{mg}$ IV bolus of atropine. Hypotension was defined as fall in blood pressure by $20 \%$ from baseline or an absolute MAP $<60 \mathrm{mmHg}$; which was manage by IV crystalloids (200ml of Ringer lactate/ normal saline) or increments of mephentermine $3 \mathrm{mg}$ IV.

Data was checked, entered and analyzed using SPSS version 24 for windows (IBM corp., Armonk, NY, USA). Quantitative data was represented as mean \pm standard deviation, and for qualitative data; number and percentages was used. Student "t-test" was used as test of significance to find as association for quantitative data. Chi-square test was used as test of significance to find the association for qualitative data. $\mathrm{P}$ value $<0.05$ was considered significance.

\section{RESULTS}

Total fifty (50) patients posted for upper limb surgeries were enrolled in the study. Both groups were comparable in terms of age, weight and sex, ASA grading (Table 1) and baseline hemodynamic parameters (Table 2).

\begin{tabular}{|llll|}
\hline \multicolumn{4}{|l|}{$\begin{array}{l}\text { Table 1. The demographic data and surgical } \\
\text { characteristics. }\end{array}$} \\
\hline $\begin{array}{l}\text { Demographic } \\
\text { Parameter }\end{array}$ & $\begin{array}{l}\text { Group Rd } \\
{[\text { [mean } \pm \text { SD] }}\end{array}$ & $\begin{array}{l}\text { Group RD } \\
\text { [mean } \pm \text { SD] }\end{array}$ & P value \\
Age [years] & $37.28 \pm 12.87$ & $40.48 \pm 15.96$ & 0.439 \\
Sex [M:F] & $16: 09$ & $15: 10$ & 0.5 \\
Weight [kgs] & $57.00 \pm 2.98$ & $55.72 \pm 0.164$ & 0.164 \\
ASA [I:II] & & $21: 04$ & 0.349 \\
\hline
\end{tabular}

\begin{tabular}{|c|c|c|c|}
\hline $\begin{array}{l}\text { Baseline } \\
\text { hemodynamic } \\
\text { Parameter }\end{array}$ & $\begin{array}{lr}\text { Group } & \text { Rd } \\
{[\text { mean } \pm \text { SD] }}\end{array}$ & $\begin{array}{l}\text { Group RD } \\
{[\text { mean } \pm \text { SD] }}\end{array}$ & $\begin{array}{l}P \\
\text { value }\end{array}$ \\
\hline HR [bpm] & $79.68 \pm 13.58$ & $79.28 \pm 10.50$ & 0.908 \\
\hline SP [\%] & $96.76 \pm 1.422$ & $96.28 \pm 1.422$ & 0.199 \\
\hline SBP [mmHg] & $134.48 \pm 12.36$ & $140.84 \pm 16.16$ & 0.125 \\
\hline DBP [mmHg] & & $82.48 \pm 10.17$ & 0.2 \\
\hline
\end{tabular}

The mean onset for sensory and motor blocks in group $\mathrm{Rd}$ were $9.36 \pm 1.114$ and $14.40 \pm 1.528$ minutes, $(\mathrm{p}=0.066)$ respectively and for group $\mathrm{RD}$ were $8.32 \pm 0.945$ and $12.40 \pm 1.414$ minutes $(p=0.50)$ respectively (Table3).

\begin{tabular}{|llll|}
\hline \multicolumn{4}{|c|}{ Table 3. Onset of sensory and motor block } \\
\hline Variables & $\begin{array}{l}\text { Group Rd } \\
\text { [mean } \pm \text { SD] }\end{array}$ & $\begin{array}{l}\text { Group RD } \\
{[\text { mean } \pm \text { SD] }}\end{array}$ & $\begin{array}{l}\text { P } \\
\text { value }\end{array}$ \\
$\begin{array}{l}\text { Onset of sensory } \\
\text { block [Minutes] }\end{array}$ & $9.36 \pm 1.114$ & $8.32 \pm 0.945$ & 0.066 \\
$\begin{array}{l}\text { Onset of motor } \\
\text { block (Minutes) }\end{array}$ & $14.40 \pm 1.528$ & $12.40 \pm 1.414$ & 0.5 \\
\hline $\begin{array}{l}P \text { value < }<0.05 \text {-significant } \\
\text { significant }\end{array}$ & $P$ value $<0.001-$ highly \\
\hline
\end{tabular}

The mean duration for sensory and motor blocks in

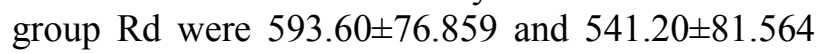
minutes $(\mathrm{p}=0.465)$, respectively and for group $\mathrm{RD}$ were $730.80 \pm 65.187$ and $659.60 \pm 93.607$ minutes $(p=0.686)$ respectively (Table 4).

\begin{tabular}{|c|c|c|c|}
\hline Variables & $\begin{array}{l}\text { Group Rd } \\
{[\text { mean } \pm \text { SD] }}\end{array}$ & $\begin{array}{l}\text { Group RD } \\
{[\text { mean } \pm \text { SD] }}\end{array}$ & $\begin{array}{l}P \\
\text { value }\end{array}$ \\
\hline $\begin{array}{lr}\begin{array}{l}\text { Duration } \\
\text { sensory }\end{array} & \text { of } \\
\text { (Minutes) } & \end{array}$ & $\begin{array}{l}593.60 \pm \\
76.859\end{array}$ & $\begin{array}{l}730.80 \pm \\
65.187\end{array}$ & 0.465 \\
\hline $\begin{array}{l}\text { Duration of mo- } \\
\text { tor } \\
\text { (Minutes) }\end{array}$ & $\begin{array}{l}541.20 \pm \\
81.564\end{array}$ & $\begin{array}{l}659.60 \pm \\
93.607\end{array}$ & 0.686 \\
\hline
\end{tabular}

The mean duration of analgesia in group $\mathrm{Rd}$ was $626.00 \pm 70.475$ and group RD was $754.00 \pm 60.139$ $(\mathrm{p}=0.577)$ (Table 5).

\begin{tabular}{|c|c|c|c|}
\hline Variables & $\begin{array}{l}\text { Group Rd } \\
{[\text { mean } \pm \text { SD] }}\end{array}$ & $\begin{array}{l}\text { Group } \\
{[\text { mean } \pm \text { SD] }}\end{array}$ & $\begin{array}{l}P \\
\text { value }\end{array}$ \\
\hline $\begin{array}{l}\text { Duration of an- } \\
\text { algesia [Minutes] }\end{array}$ & $\begin{array}{l}626.00 \pm 70.4 \\
75\end{array}$ & $\begin{array}{l}754.00 \pm 60.13 \\
9\end{array}$ & 0.577 \\
\hline
\end{tabular}

There were no significant differences in the heart rate, systolic $\mathrm{BP}$, diastolic $\mathrm{BP}$, mean $\mathrm{BP}$ and oxygen saturation between the groups measured at 10,15 , $30,45,60,90,120$ mins and 4, 6, 12, 18 and 24hrs. Sedation score between two groups were statistically significant. In group Rd, most patient have sedation score of 1 or 2 whereas in group RD, most patient have higher sedation score of 2 or 3 (Table 6).

\begin{tabular}{|c|c|c|c|}
\hline Variables & Group Rd & Group RD & $P$ value \\
\hline $\begin{array}{l}\text { Sedation score } \\
{[1: 2: 3]}\end{array}$ & 6:19:00 & 1:15:09 & 0.001 \\
\hline
\end{tabular}


Three patients in group RD and none in group Rd had complications which was statistically not significant $(\mathrm{p}=0.074)$. Three patients in group $\mathrm{RD}$ developed bradycardia which was treated with inj. Atropine. Other complications like: nausea, vomiting, hypoxemia, pruritus, urinary retention were not observed in either groups.

\section{DISCUSSION}

In our prospective, randomized, double-blinded trial, we compared the effects of $1 \mathrm{mcg} / \mathrm{kg}$ and $2 \mathrm{mcg} / \mathrm{kg}$ dexmedetomidine with $0.5 \%$ plain ropivacaine in USG guided supraclavicular brachial plexus block for onset time, duration of sensory and motor block, post-operative analgesia, complications and hemodynamic changes. The demographic profileand baseline hemodynamic parameters between two groups were similar ( $p$ value $>0.05)$. The onset time of sensory block $(9.36 \pm 1.114$ mins in group $\mathrm{Rd}$ Vs $8.32 \pm$ $0.945 \mathrm{mins}$ in group RD) were not significantly different between two groups ( $\mathrm{p}$-value $>0.05$ ). The onset time of motor block (14.40 $\pm 1.528 \mathrm{mins}$ in group $\mathrm{Rd}$ Vs $12.40 \pm 1.21$ mins in group $\mathrm{RD}$ ) were not significantly different between two groups ( $\mathrm{p}$ value $>0.05$ ). These findings correlated with the studies done by Thakur et al., ${ }^{13}$ Balkrishnan et al., ${ }^{14}$ Joseph et al. ${ }^{15}$ In our study, the duration of sensory block $(596.20 \pm 76.859$ mins in group Rd Vs $730.80 \pm 65.187$ mins in group RD) were not significantly longer in group RD than group Rd (pvalue $>0.05)$. The duration of motor block $(541.20 \pm 81.564$ mins in group $\mathrm{Rd} \mathrm{Vs}$ $659.80 \pm 93.607$ mins in group RD) was not significantly longer in group RD than group Rd (pvalue $>0.05)$. The duration of analgesia $(626.00 \pm 70.475$ mins in group $\mathrm{Rd} \mathrm{Vs}$ $754.00 \pm 60.139$ mins in group RD) was significantly longer in group RD than group $\mathrm{Rd}(\mathrm{p}$ value $>0.05$ ). These findings correlated with the studies done by Thakur et al., ${ }^{13}$ Balkrishnan et al., ${ }^{14}$ Joseph et al. ${ }^{15}$ Dexmedetomidine added as an adjuvant shortens the onset of sensory and motor block as well as prolongs the duration of sensory and motor block and duration of analgesia. ${ }^{13-18}$ But the ideal dose of dexmedetomidine as an adjuvant is not defined. Here, we compared $2 \mathrm{mcg} / \mathrm{kg}$ and $1 \mathrm{mcg} /$ $\mathrm{kg}$ of dexmedetomidine added to ropivaciane in terms of onset of sensory and motor block as well as duration of sensory and motor block and duration of analgesia. We find no statistically different results in between two groups. Thakur et al., ${ }^{13}$ Balkrishnan et al., ${ }^{14}$ Joseph et al., ${ }^{15}$ also did not find any difference between two doses of dexmedetomidine as an adjuvant to local anesthetics. Sedation score were higher in $\mathrm{RD}$ group than $\mathrm{Rd}$ group but were not significantly different between two groups ( $p$-value $>$ $0.05)$. Hemodynamic parameters were also comparable between two groups ( $p$-value $>0.05$ ) but 3 patients in RD group $(2 \mathrm{mcg} / \mathrm{kg})$ developed bradycardia and required treatment with atropine whereas in $\mathrm{Rd}$ group $(1 \mathrm{mcg} / \mathrm{kg})$ none developed bradycardia. Complications developed with higher doses of dexmedetomidine. ${ }^{13-17}$ So, in comparison to $2 \mathrm{mcg} / \mathrm{kg}$ dexmedetomidine, $1 \mathrm{mcg} / \mathrm{kg}$ would be ideal dose as adjuvant to local anesthetics to shorten onset of block, prolong duration of block and analgesia as well as decrease the complications related to dexmedetomidine.

We could identify following limitation to our study, type of surgery and tourniquet time were not included in our study and assessment of postoperative sensory and motor block were subjective.

\section{CONCLUSIONS}

There is no difference in duration of analgesia between $1 \mathrm{mcg} / \mathrm{kg}$ dexmedetomidine and $2 \mathrm{mcg} / \mathrm{kg}$ of dexmedetomidine as an adjuvant to local anesthetics in supraclavicular brachial plexus block. However, because of lesser trend of side effect with the lower dose, though not statistically significant, we conclude that $1 \mathrm{mcg} / \mathrm{kg}$ dexmedetomidine should be used as optimum dose as adjuvant to local anesthetic than $2 \mathrm{mcg} / \mathrm{kg}$ of dexmedetomidine while giving a brachial block.

\section{REFERENCES}

1. Moore DC, Bridenbaugh LD, Eather KF. Block of the upper extremity. Arch Surg. 1965 Jan; 90: 68-72.

2. Hanumanthaiah D, Vaidyanathan S, Garstka M. Ultrasound guided supraclavicular block. Med Ultrason 2013; 15: 224-9.

3. Sanghvi KS, Shah VA, Patel KD. Comparative study of bupivacaine alone and bupivacaine along with buprenorphine in axillary brachial

plexus block: a prospective, randomized, single blind study. Int J Basic ClinPharmacol. 2013; 2: 640-44.

4. Biradar PA, Kaimar P, Gopalakrishna K. Effect of dexamethasone added to lidocaine in supraclavicular brachial plexus block. A prospective, randomized, double blind study. Indian J Anesth. 2013; 57:180-84.

5. Lee AR, Yi HW, Chung IS, Ko JS et al. Magnesium added to bupivacaine prolongs the duration of analgesia after interscalene nerve 


\section{Singh et al. Comparative Study Between Two Different Doses of Dexmedetomidine.}

block. Can J Anesth. 2012; 59: 21-27.

6. Shaikh SI, Veena K. Midazolam as an adjuvant in supraclavicular brachial plexus block. Anaesth Pain and Intensive care. 2012; 16: 7-11.

7. Kohli S, Kaur M, Sahoo S. Brachial plexus block. Comparison of two doses of clonidine added to bupivacaine.

AnesthsiolClinPharmcol. 2013 Oct; 29(4): 4915.

8. Hutschala D, Mascher H, Schemetter L. Clonidine added to bupivacaine enhances and prolongs analgesia after brachial plexus block via a local mechanism in healthy volunteers. European European J Anesth 2004; 21(3):198204.

9. Kettner SC. Dexmedetomidine as adjuvant for peripheral nerve blocks. Br J Anaesth. 2013 jul; 111(1): 123.

10. Das A, Majumdar S, Halder S, et al. Effects of dexmedetomidine as adjuvant in ropivacianeinduced supraclavicular brachial plexus block: A prle blinded and randomized controlled study. Saudi J Anesth. 2014; 8(1): 72-7.

11. Gandi R, Shah A, Patel I. Use of dexmedetomidine along with bupivacaine for brachial plexus block. Natl J Med Res. 2012; 2: 67-9.

12. Robaux S, Blunt C, Viel E et al. Tramadol added to $1.5 \%$ mepivacaine for axillary brachial plexus block improves postoperative dose-dependently. AnesthAnalg. 2004; 98: 1172-77.

13. Thakur S, Singh J, Kumar S et al. Efficacy of Dexmedetomidine in two different doses as an adjuvant to lignocaine in patients scheduled for surgeries under axillary block. Journal of clinical and Diagnostic research. 2017 Apr; 11(4): 1621

14. Balakrishnan S, Kunikkakath S, Jacob KK, Shenoy $\mathrm{M}$ et al. Comparative study on the clinical profile of different doses of dexmedetomidine with levobupivaciane in supraclavicular brachial plexus block. Indian Journal of Clinical anesthesia; 2016; 3(3): 432438.

15. Joseph EJ, Vasukinathan A, Dhanalakmi B et al. Comparision of three different doses of dexmedetomidine as adjuvant to bupivacaine in supraclavicular brachial plexus block for upper limb orthopedic surgeries. International Journal of scientific research; 2017 Dec; 6(12); 23-25.

16. Agrawal S, Agrawal R, Gupta P. Dexmedetomidine prolongs the effect of bupivacaine in supraclavicular brachial plexus block, Journal of Anesthesiology clinical pharmacology. 2014; 30(1):36-40.

17. Ammar S A,Mahmaud K M. USG guided single injection infraclavicular brachial plexus block using bupivaciane alone or combined with dexmedetomidine for pain control in upper limb surgery: A prospective randomized controlled trial, Saudi Journal Anaesthseia. 2012; 6(2):109114.

18. Kaygusuz K, Kol I O, Duger C. Effects of adding dexmedetomidine to levobupivacaine in Axillary brachial plexus block, Current Therapeutic Research. 2012; 73(3):103-11.

Citation: Singh J, Shakya S, Ghimire A, Saha S, Singh PB. Comparative Study Between Two Different Doses of Dexmedetomidine Combined with Ropivacaine in Ultrasound Guided Supraclavicular Brachial Plexus Block. JCMS Nepal. 2018;14(3):127-31 